\title{
ANÁLISE DE EPISÓDIOS DE ALAGAMENTOS E INUNDAÇÕES URBANAS NA CIDADE DE SÃO CARLOS A PARTIR DE NOTÍ́CIAS DE JORNAL ${ }^{1}$
}

\author{
LIMA, Altieris Porfírio - altierislima@yahoo.com.br \\ Universidade Estadual Paulista - Presidente Prudente \\ AMORIM, Margarete Cristiane de Costa Trindade - mccta@fct.unesp.br \\ Universidade Estadual Paulista - Presidente Prudente
}

\begin{abstract}
RESUMO: O aumento da concentração populacional nas áreas urbanas brasileiras, ocorrido principalmente a partir da segunda metade do século $X X$, tem como um de seus reflexos os graves problemas socioambientais observados atualmente. Frequentemente, episódios de precipitações, que fazem parte da variabilidade climática natural de áreas tropicais, deflagram diversos transtornos e inúmeras perdas entre a população em diversas cidades. Considerandose os riscos associados às precipitações existentes nas cidades brasileiras o estudo teve como objetivo a análise da ocorrência de episódios de alagamentos e inundações ocorridos entre 1980 e 2009 na cidade de São Carlos/SP, tendo como referencial teórico metodológico o Sistema Clima Urbano (Monteiro, 1976), Subsistema Hidrometeórico. O estudo foi desenvolvido através da análise associada entre dados pluviais de São Carlos e notícias sobre as repercussões dos impactos deflagrados pela precipitação veiculados em jornais locais. Os resultados revelaram que, embora a ocorrência de alagamentos e inundações em São Carlos seja considerada fato antigo - haja vista que os estudos de Mendes et al. (2005) já indicavam a existência de tais episódios desde meados do século XX - houve um grande aumento do número de ocorrências e surgimento de novas áreas atingidas por esses impactos, especialmente a partir do final da década de 1990, como reflexo da expansão urbana de São Carlos e do aumento da concentração das chuvas, principalmente nos casos de grandes volumes de precipitação em $24 \mathrm{~h}$.
\end{abstract}

Palavras chave: Clima Urbano; Precipitação; Impactos pluviais; Notícias de jornal; São Carlos. OVERFLOW AND URBAN FLOODING ANALYSIS IN SÃO CARLOS (BRAZIL) BY THE NEWSPAPER NEWS

ABSTRACT: The increasing concentration of population in Brazil urban areas, occurred mainly from the second half of the twentieth century, has as one of its consequences the serious social and environmental problems currently observed. Often episodes of rainfall that are part of natural climate variability in tropical areas trigger disorders and countless losses among the population in various cities. Thinking about the risks associated with precipitation in Brazilian cities, the study aimed to analyze the occurrence of flood and flooding episodes that occurred between 1980 and 2009 in São Carlos/SP, having as theoretical and methodological referential of the Urban Climate System (MONTEIRO, 1976), Hydrometeoric Subsystem. The study was developed through the joint analysis between precipitation data in São Carlos and the news about impacts triggered by rainfall recorded in local newspapers. The results revealed that although the occurrence of flooding and flood in São Carlos city is considered really old Mendes et al. (2005) indicated the existence of such episodes since the mid-twentieth century - there was a large increase in the number of occurrences and the new areas affected by these impacts, especially from the end of the 1990s, reflecting the urban expansion of São Carlos and the increased concentration of rainfall, especially in large volumes of precipitation cases in 24 hours.

Keywords: Urban Climate; Precipitation; Impacts of rain; Newspaper; São Carlos.

\footnotetext{
${ }^{1}$ Esta pesquisa foi desenvolvida com apoio da FAPESP (Fundação de Amparo a Pesquisa do Estado de São Paulo).
} 


\title{
1. INTRODUÇÃO
}

O crescimento populacional urbano e suas demandas se refletem em uma série de problemas socioambientais que se evidenciam cotidianamente em cidades de todo o mundo.

\begin{abstract}
O processo de urbanização atingiu, no final do século XX e início do XXI, índices bastante elevados, resultando que na atualidade a população do planeta é, majoritariamente, urbana. Esta condição engendra uma série de novos e complexos problemas para a compreensão e gestão do espaço e da sociedade urbana, sendo que aqueles de ordem socioambiental encontram-se destacados no contexto das cidades, particularmente daquelas de países em condições socioeconômicas de alta complexidade, como é o caso do Brasil (MENDONÇA, 2004, p. 140).
\end{abstract}

A partir da segunda metade do século $X X$, muitas cidades brasileiras registraram um aumento populacional acelerado e tal fato, como destaca Oliveira (1998, p.2), contribuiu para o "desencadeamento de situações vinculadas à ausência de planejamento para subsidiar o processo de expansão urbana".

A análise dos cenários urbanos brasileiros revela a forma desordenada de apropriação, norteado pela ausência de planejamento que considere o disciplinamento do uso e ocupação do solo como prerrogativa básica de seu ordenamento. Essa desordenação traz como conseqüência, níveis abusivos de degradação ambiental evidentes no cotidiano urbano (OLIVEIRA, 1998, p. 3).

A ocupação indiscriminada de áreas impróprias, especialmente aquelas atualmente denominadas Áreas de Preservação Permanente, evidencia um grave problema socioambiental produzido e reproduzido nos centros urbanos desde a fundação das primeiras cidades brasileiras até os dias atuais e se expressa no elevado grau de vulnerabilidade às enchentes ${ }^{2}$.

As alterações no ambiente natural produzidas pelo processo de urbanização em São Carlos/SP, especialmente em relação ao uso e ocupação do solo, resultaram em consequências que não foram previamente calculadas na fase inicial da fundação do núcleo urbano e em sua expansão. O reflexo dessa situação atualmente se tornou um dos principais problemas socioambientais registrados na cidade, que é a vulnerabilidade a impactos ${ }^{3}$ deflagrados por episódios de precipitações, tais como alagamentos ${ }^{4}$ e inundações ${ }^{5}$ urbanas.

\footnotetext{
${ }^{2}$ As enchentes podem ser consideradas uma das consequências da atuação e dinâmica de sistemas naturais sobre a superfície terrestre que maiores alterações provocam no espaço geográfico. Essa dinâmica não se restringe apenas ao aumento da vazão que leva à enchente, mas também aos movimentos atmosféricos, aos processos geomorfológicos e, principalmente, às repercussões ocorridas nas áreas afetadas pelas enchentes, em especial nas áreas urbanas situadas às margens dos rios, onde são processos freqüentes. (...) As enchentes, quando estudadas dentro de uma perspectiva climática, acabam tendo abordagem diferente da observada nas linhas de pesquisa da geomorfologia. Nessa perspectiva, as enchentes passam a ser vistas como azares da natureza, os quais o homem está freqüentemente submetido e, nesse ínterim, prevenir-se das catástrofes passa a ser um dos grandes objetivos da relação dos seres humanos com o clima (WOLLMAN e SARTORI, 2008, p.2). De acordo com Maia (2007, p. 20) as "cheias" do curso fluvial é o termo técnico correto para descrever esta ação fluvial; no entanto, as "enchentes" foi um termo popular assimilado pela ciência. Qualquer um dos termos escolhidos se refere aos fenômenos naturais que ocorrem dentro de uma bacia hidrográfica.

${ }^{3}$ Segundo Maia (2009, p. 7) para definição do termo impacto é preciso, atualmente, reflexão sobre o seu significado conforme as diferentes correntes do pensamento contemporâneo. Gonçalves (1992, p. 7 apud Garcia, 1982) assinala impacto como a expressão das transformações que decorrem de um determinado evento em determinado meio, seja econômico, social, político ou ambiental. Portanto para a autora, impacto sempre está associado à idéia de algo forte, que representa choque ou colisão.

${ }^{4}$ Os alagamentos estão restritos as áreas urbanas, fruto das fortes chuvas sobre um ambiente extremamente urbanizado e solo intensamente impermeabilizado (WOLLMAN e SARTORI, 2008, p.2). De acordo com Grilo (1992), os alagamentos ocorrem, de modo geral, em áreas planas ou com depressões e fundos de vales, com o escoamento superficial comprometido pela topografia e falta ou insuficiência de um sistema pluvial no ambiente urbano. Ainda,
} 
A cidade de São Carlos foi fundada próxima à margem direita do córrego do Gregório, área onde atualmente se concentra grande parte dos problemas associados à drenagem urbana.

As cidades "ribeirinhas" atualmente padecem da urbanização empreendida no passado, quando as inundações se destacam nas áreas urbanas na estação das "águas". Não é preciso uma chuva de grande monta para que os cursos d'água provoquem a derrubada de pontes, inundem casas e vias de circulação. O céu com nuvens pretas traz para as pessoas uma sensação de insegurança do que está por vir. Isto pode ser verificado no comportamento da cidade, vistos os congestionamentos de tráfego de veículos e sua circulação desordenada (MAIA, 2007, p. 5).

Mendes et al. (2005) baseando-se em registros históricos, esclarecem que a cidade de São Carlos já apresentava área sujeita à ocorrência de inundações desde os primórdios de sua expansão urbana, ainda no final da década de 1940, mas tal vulnerabilidade não foi considerada naquele momento, o que permitiu a ocupação indiscriminada de áreas de várzea e fundos de vale. Atualmente as principais áreas de ocorrência de inundações e alagamentos localizam-se nas imediações da região central da cidade (Figura 1), em vias de grande importância para circulação do trânsito local (avenidas situadas próximo às margens de alguns córregos urbanos) e na principal área comercial do centro da cidade (área localizada em fundo de vale e em planície aluvial).

Os frequentes episódios de alagamentos e inundações registrados em São Carlos nos últimos anos ressaltam a relevância do estudo, haja vista os transtornos e perdas sofridos pela população atingida por esses impactos recorrentes. Amorim (2000, p. 309) ao ressaltar a importância de se estudar as áreas urbanas tendo em vista que as cidades brasileiras concentram atualmente a maior parte da população do país. Além disso, recentemente questões relativas às vulnerabilidades presentes em áreas urbanas têm despertado ainda mais a atenção de pesquisadores de diversas áreas do conhecimento.

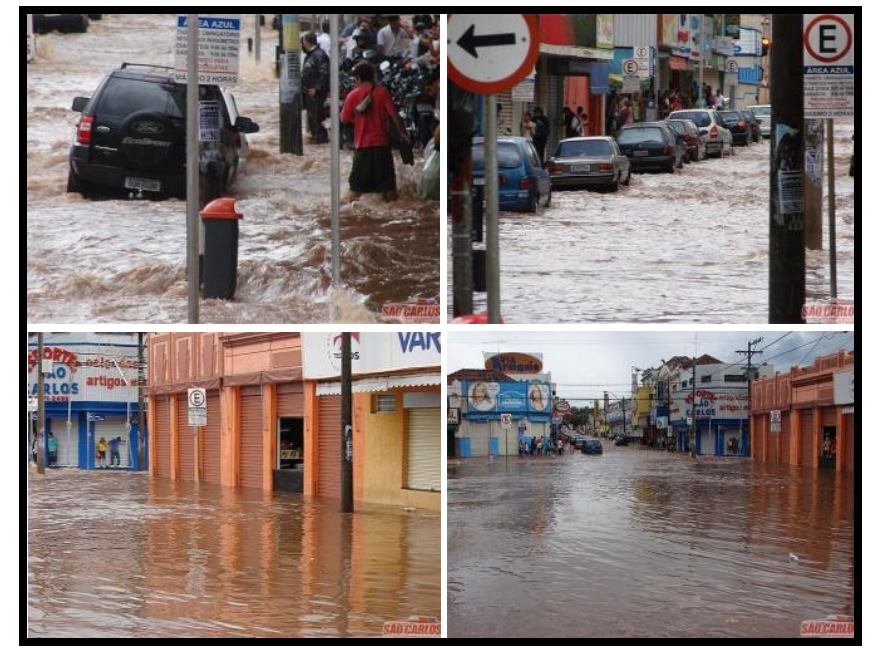

Figura 1: Inundação no fundo de vale do Mercado Municipal, 19/12/2007.

Fonte: Emerson José Ferreira/São Carlos Agora.

quanto menor a extensão de áreas verdes, menor a infiltração de água no solo e, conseqüentemente, menor auxílio para o escoamento superficial, as quais poderiam atenuar as causas dos mesmos.

${ }^{5}$ Para Maia (2009, p. 20) existe uma pequena confusão conceitual quando se designa este fenômeno hidrológico: o termo inundação. Há uma diferença entre enchente e inundação. O primeiro se refere a águas que extravasam o leito menor dos rios; a inundação é um fenômeno geomorfológico que ocorre no período de cheia, quando as águas fluviais extravasam o canal fluvial, inundando a região. 
Considerando tais questões a pesquisa teve como objetivo principal analisar a ocorrência de impactos deflagrados pela precipitação, especificamente episódios de alagamentos e inundações urbanas ocorridos entre 1980 e 2009 na cidade de São Carlos/SP, com a finalidade de compreender os processos causadores desses impactos.

\section{CARACTERIZAÇÃo dA ÁREA DE ESTUdo}

O município de São Carlos localiza-se no planalto das Cuestas da Serra Geral na região central do estado de São Paulo (Figura 2), inserida dentro do quadrante $21^{\circ}$ $30^{\prime}$ e $22^{\circ} 30^{\prime}$ latitude sul e $47^{\circ} 30^{\prime}$ e $48^{\circ} 30^{\prime}$ longitude oeste, a uma altitude média de 856 metros. Integra a Região Administrativa Central do estado de São Paulo e caracteriza-se como importante pólo tecnológico e educacional.

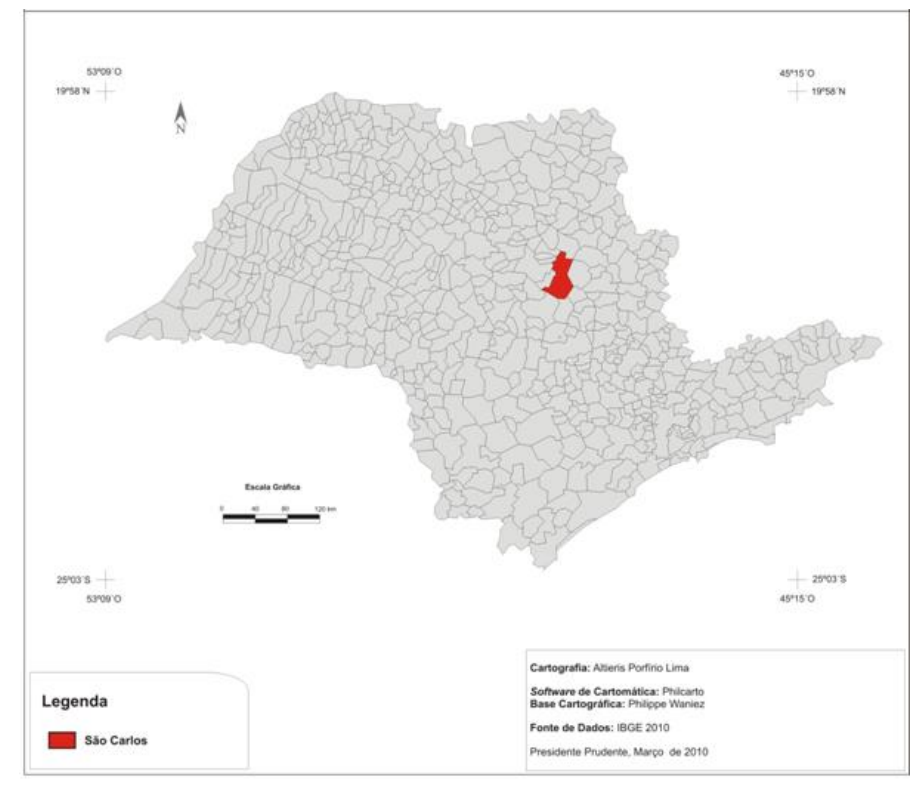

Figura 2: Localização do município de São Carlos.

É uma cidade de médio porte, com 221.936 habitantes segundo Censo do IBGE em 2010, concentrando na área urbana $96 \%$ de sua população. A área urbana do município é de $67,25 \mathrm{~km}^{2}$, apenas $6 \%$ da área total do território municipal (que é de $1.140,92 \mathrm{Km}^{2}$ ), e sua densidade demográfica é de $201,95 \mathrm{hab} / \mathrm{km}^{2}$ (superior à média do estado que é de $169,76 \mathrm{hab} / \mathrm{km}^{2}$ ).

O relevo na área urbana se destaca das áreas circunvizinhas, com altitudes inferiores. Tolentino (2007, p.22) afirma que "o exame da rede de drenagem da região revela também essa situação" constituindo-se um divisor de águas entre as bacias de drenagem do Rio Pardo (via Mogi-Guaçu) ao norte, e do Rio Tietê (via Jacaré-Guaçu) ao sul. No setor norte do território municipal localiza-se as microbacias das Araras, Mogi-Guaçu, das Guarirobas, das Cabaceiras, Chibarro, do Quilombo e do Pântano, que pertencem à UGRHI Mogi-Guaçu. Na parte sul está as microbacias do Monjolinho, do Feijão e do Jacaré-Guaçu, pertencentes à UGRHI Tietê - Jacaré.

A Figura 3 apresenta o limites das microbacias do município e a Figura 4 os limites das sub bacias da área urbanizada de São Carlos. É importante destacar na Figura 4 que praticamente toda a área urbanizada está inserida na microbacia do córrego do Monjolinho. 


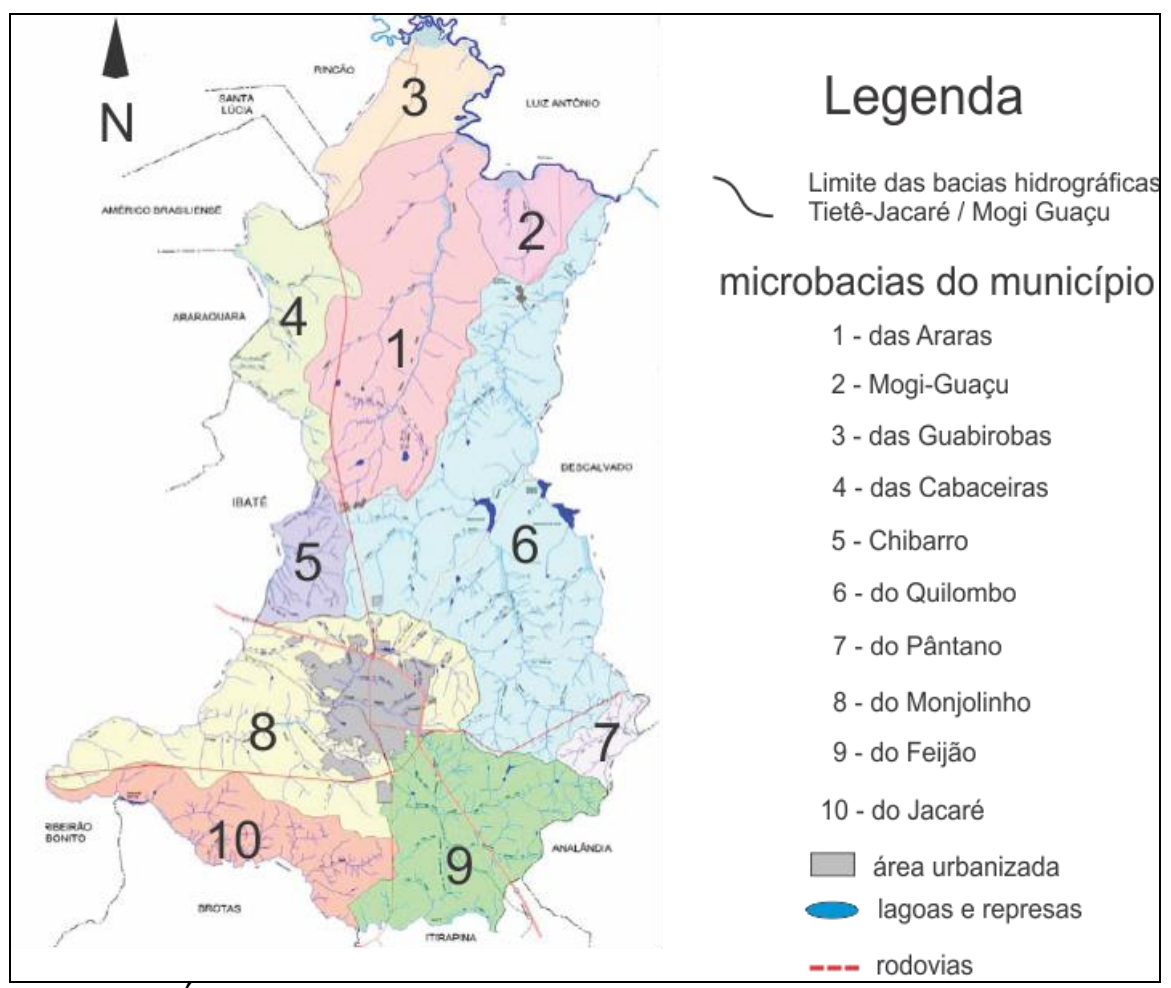

Figura 3: Área urbanizada e as microbacias do município de São Carlos Fonte: Prefeitura Municipal de São Carlos. Adaptado do Plano Municipal de Saneamento - São Carlos/SP 


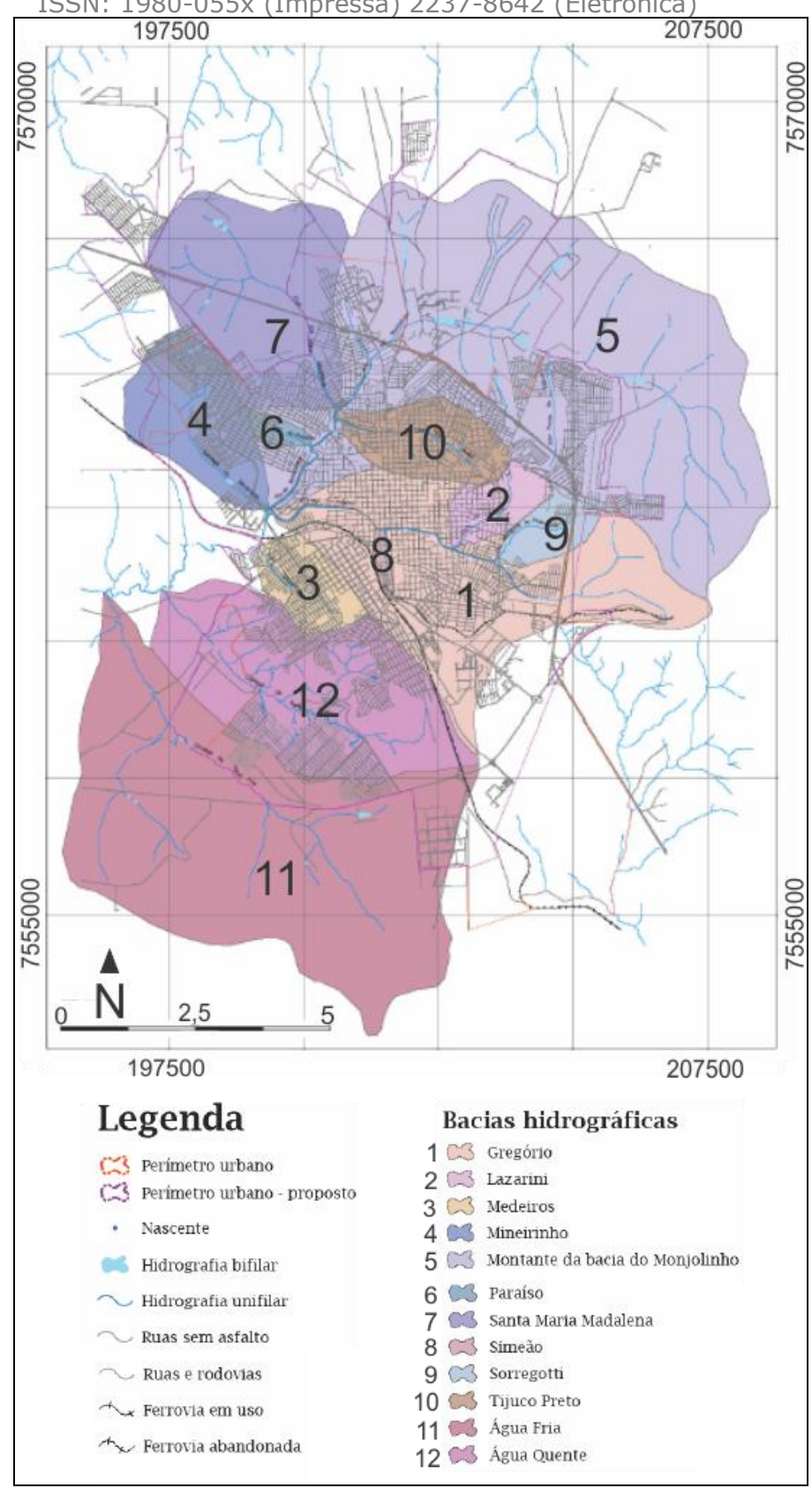

Figura 4: Sub bacias urbanas de São Carlos.

Fonte: Prefeitura Municipal de São Carlos. Adaptado do Plano Municipal de Saneamento - São Carlos/SP

\section{A OCUPAÇÃO INICIAL DA REGIÃO E FUNDAÇÃO DE SÃO CARLOS}

A exploração da região onde hoje se encontra o município de São Carlos deu-se no contexto dos movimentos de penetração e conquista do território paulista pelos bandeirantes. O início da ocupação legal de terras no atual município de São Carlos ocorreu ainda no século XVIII, entretanto de acordo com Devescovi (1987, p. 23) "a efetiva fixação do homem na região foi determinada pela chegada da lavoura do café". Todavia, a cultura cafeeira só se tornou a principal atividade da região a partir de 1884, com a chegada da ferrovia e de um contingente crescente de mão de obra estrangeira para trabalhar na lavoura.

Segundo Devescovi (1987, p. 45) quando os imigrantes "conseguiam desamarrar-se de seus compromissos com os fazendeiros de café, dirigiam-se às cidades, tentando integrarem-se ao mercado de trabalho urbano". O autor destaca 
ainda que a partir do início da decadência da cafeeira no inicio do século $X X$, o deslocamento da população do campo para a cidade trouxe dinâmica a alguns centros urbanos, como ocorreu em São Carlos.

A expansão do núcleo urbano inicial, segundo Oliveira (1998, p. 83), deu-se na direção norte-sul e a cidade passou a ser adensada por meio de loteamentos espontâneos. Até o início do século XX a cidade de São Carlos tinha uma população constituída principalmente pela burguesia agrária, comerciantes, profissionais liberais e pequenos proprietários rurais. Devescovi (1987, p. 183) esclarece que o núcleo urbano de São Carlos, até os anos 1970, "possuía uma ocupação extremamente rarefeita, a tal ponto que uma das preocupações correntes já no final da década de 1940, era a existência de uma enorme quantidade de terrenos desocupados na interior da cidade".

Segundo a prefeitura municipal de São Carlos em estudo realizado em 2005 para a elaboração do Plano Diretor, a cidade se expandiu descontinuamente e ocupando áreas inadequadas como mananciais e planícies de inundação, fato que resultou nos graves problemas de drenagem dos dias atuais. De acordo com o relatório do Plano Municipal de Saneamento de São Carlos (2010) a partir da década de 1970, "o conflito entre a expansão urbana e as áreas ambientalmente frágeis se acentuou, principalmente com implantação de vias marginais e a invasão de áreas de proteção ambiental à beira dos córregos" (Figuras 5 e 6).

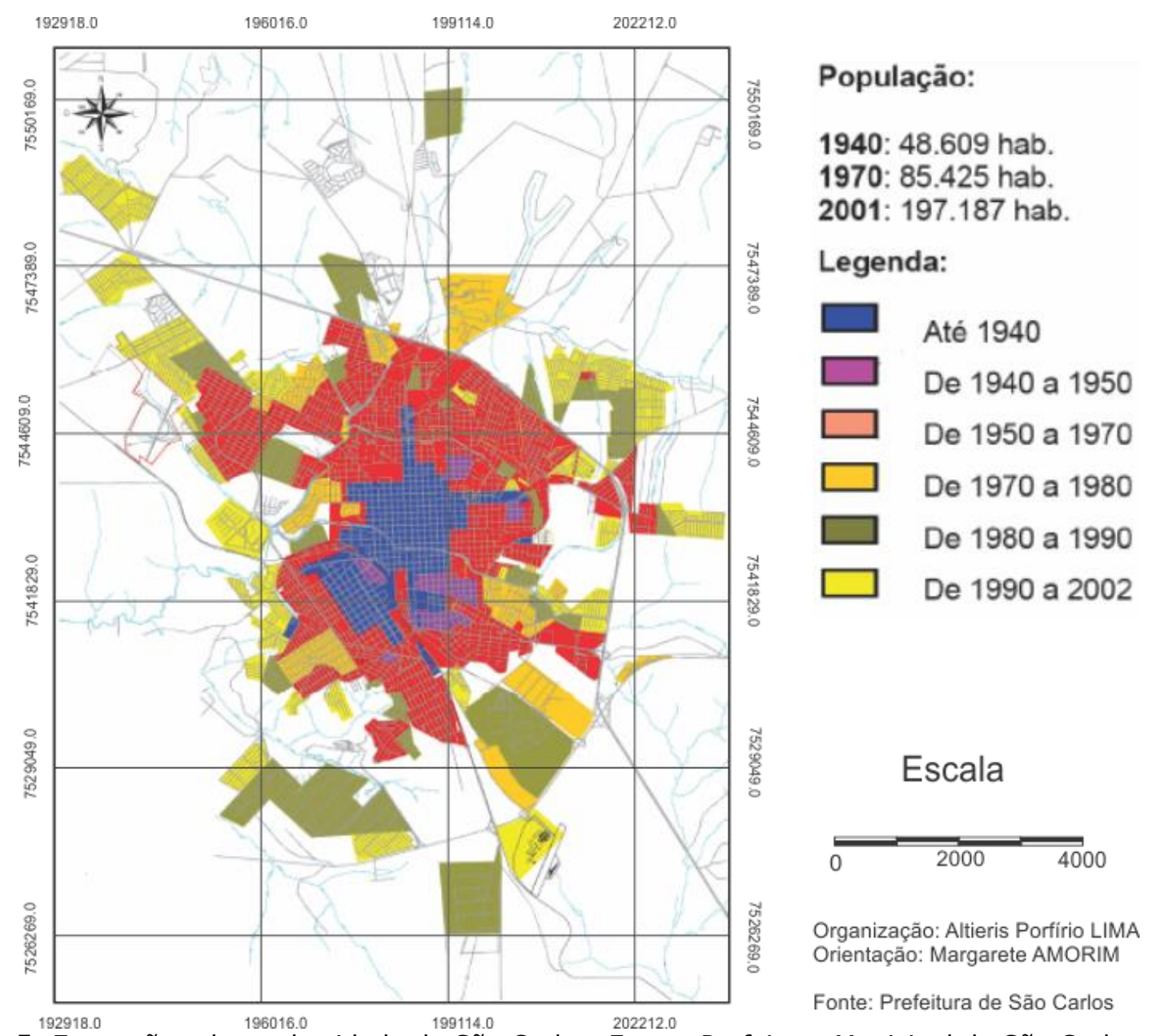

Figura 5: Expansão urbana da cidade de São Carlos. Fonte: Prefeitura Municipal de São Carlos, 2005. Adaptado do Plano Municipal de Saneamento - São Carlos/SP 


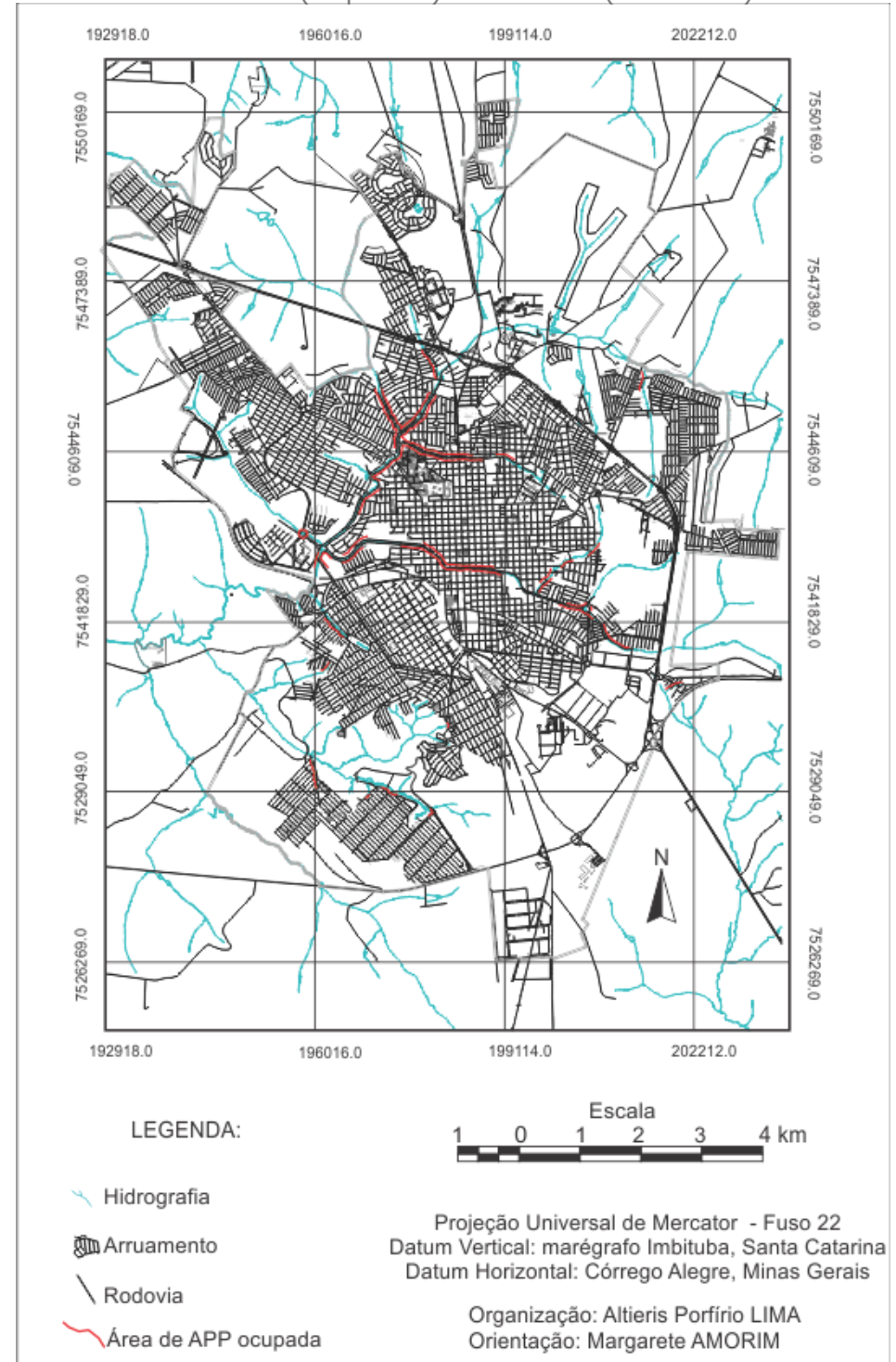

Figura 6: Áreas de Preservação Permanente ocupadas. Fonte: Prefeitura Municipal de São Carlos Adaptado do Plano Municipal de Saneamento - São Carlos/SP

\section{Procedimentos metodológicos}

O estudo dos impactos deflagrados pela precipitação na cidade de São Carlos foi desenvolvido a partir da análise da interação existente entre atmosfera e ambiente urbano, pressuposto básico em estudos de Clima Urbano. A pesquisa se concentrou na análise do recorte temporal de 1980 a 2009, período em que a cidade de São Carlos apresentou significativo crescimento populacional (Gráfico 1).

O estudo foi desenvolvido tendo como principal referencial teórico metodológico o Sistema Clima Urbano de Monteiro (1976), por meio do Subsistema Hidrometeórico (impacto meteórico), analisando a relação entre o clima, o espaço urbano e a ocorrência de impactos associados à precipitação. Os dados meteorológicos utilizados no estudo foram disponibilizados pelo INMET ${ }^{6}$ e são da Estação Meteorológica de São Carlos (estação convencional no 83726), localizada no Campus da Universidade Federal de São Carlos, situada a $47^{\circ} 88^{\prime} \mathrm{W}$ e $22^{\circ} 02^{\prime} \mathrm{S}$, a uma altitude de $856 \mathrm{~m}$.

\footnotetext{
${ }^{6}$ Instituto Nacional de Meteorologia.
} 
Os dados de precipitação diários correspondentes ao período de 1980 a 2009 foram organizados e analisados quantitativamente por meio de aplicação de técnicas estatísticas, utilizado o programa $\operatorname{EXCEL}^{7}$, com a finalidade de gerar informações detalhadas sobre as características da precipitação em São Carlos. Nesse sentido, procurou-se identificar características e tendências da distribuição anual e mensal da precipitação através de cálculos de média, desvio padrão, precipitação máxima em $24 \mathrm{~h}$, período de retorno de precipitação máxima em $24 \mathrm{~h}$ e número de dias com chuva.

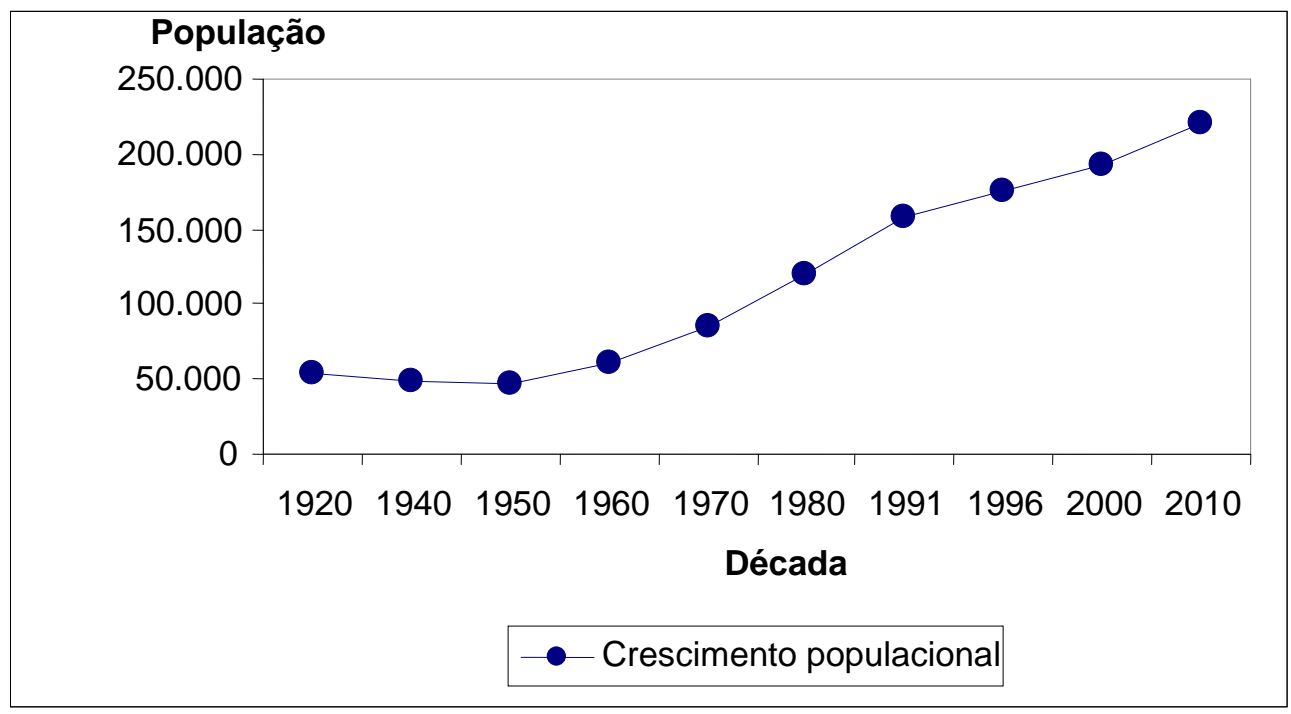

Gráfico 1: Crescimento populacional de São Carlos. Fonte: IBGE

Análise qualitativa da precipitação no espaço urbano de São Carlos foi realizada por meio do levantamento das notícias de episódios alagamentos e inundações veiculadas nos jornais locais durante o período de 1980 a 2009. A utilização de notícias da mídia impressa como fonte de dados para análises climáticas qualitativas é considerada estratégica conveniente e eficiente, haja vista que o mesmo procedimento já foi empregado nos trabalhos de Brandão (2001), Souza e Sant 'Anna Neto (2004), Souza (2005), Vicente (2005), Nunes (2007), Silveira (2007), Ely (2008), Teodoro (2008), Maia (2009), Castellano (2010), e Mendonça (2011).

As informações sobre as ocorrências de alagamentos e inundações foram pesquisadas em três jornais de São Carlos: Jornal Primeira Página, Jornal A Tribuna de São Carlos, e Jornal A Folha. Esses jornais foram consultados no acervo do arquivo público e histórico da Fundação Pró-Memória de São Carlos e no acervo da Biblioteca Jurídica da Câmara Municipal de São Carlos.

A prioridade foi analisar o jornal "Primeira Página", pois era o periódico que possuía a série histórica mais completa. Nos casos em que não havia o jornal "Primeira Página" disponível para consulta, foram analisados os demais jornais disponíveis, "A Folha" ou "A Tribuna de São Carlos".

Os jornais foram analisados manualmente, dia por dia, e as notícias encontradas relacionadas às repercussões de episódios de precipitação foram registradas através de fotografia e organizadas em planilhas utilizando o programa Excel (Tabela 1).

\footnotetext{
${ }^{7}$ Marca registrada Microsoft Office.
} 
Tabela 1: Modelo de ficha para registro das informações contidas nas notícias.

\begin{tabular}{|l|l|}
\hline \multicolumn{2}{|c|}{ Ficha de informações sobre os episódios de inundações e alagamentos } \\
\hline Jornal & \\
\hline Data & \\
\hline Cabeçalho da notícia & \\
\hline Caderno e página & \\
\hline Local e repercussões & \\
\hline Foto & \\
\hline Destaque & \\
\hline Outras observações & \\
\hline
\end{tabular}

Fonte: Adaptado de Souza, 2005

Nos jornais foram selecionadas para análise as notícias que continham algum tipo de informação relativa à ocorrência de episódios de inundações e alagamentos. É importante ressaltar que os artigos dos diferentes jornais consultados não apresentaram um consenso em relação aos termos utilizados para definição dos impactos pluviais relacionados à drenagem urbana. Nesse sentido a consulta procurou analisar os artigos que continham informações sobre enchentes, cheias, enxurradas, alagamentos e inundações.

De modo geral, as notícias encontradas nos jornais continham as datas e os locais onde ocorreram os alagamentos e as inundações e facilitaram a identificação e posteriormente o mapeamento desses pontos. Geralmente as fotografias mostravam os transtornos provocados e a área atingida. Um dado muito importante encontrado somente em algumas notícias dos jornais foi a relação tempo/volume da precipitação. Essas informações tinham como fonte a Defesa Civil do Município e demonstrava as intensidades das precipitações, fator relevante na análise do processo de alagamentos e inundações urbanas.

\section{ANÁLISE QUANTITATIVA DOS DADOS PLUVIAIS}

Os dados pluviais do período de 1980 a 2009 foram analisados quantitativamente com o objetivo de indicar as características da precipitação, principalmente em relação a seu padrão de distribuição. A Estação Meteorológica do INMET - 83726 foi selecionada para a coleta dos dados pluviais por ser a estação mais próxima da cidade e por isso a mais representativa da área urbana. Além disso, a Estação do INMET possui a série histórica de dados pluviais mais completa dentre as estações citadas. As poucas falhas foram supridas por dados das Estações Meteorológica do DAEE (D4 - 075) da EMBRAPA.

Os dados pluviais diários foram organizados e tratados através de técnicas estatísticas utilizando o programa EXCEL. Foram calculados os totais mensais e anuais, as médias, os desvios padrões, o número de dias com chuva, a precipitação máxima em 24h. Após a aplicação destas técnicas estatísticas foram elaborados gráficos e tabelas para auxiliarem as análises. Os dados pluviais registrados durante esses 30 anos apresentaram média anual de 1566,1 mm; sendo que os anos de 1980, 1983, 2000 e 2009 registraram precipitação acima do padrão considerado normal; os anos de 1981, 1984, 2003 e 2008 apresentaram precipitação abaixo do padrão habitual, e o restante dos anos foi classificado como dentro do padrão (Gráficos 2). 


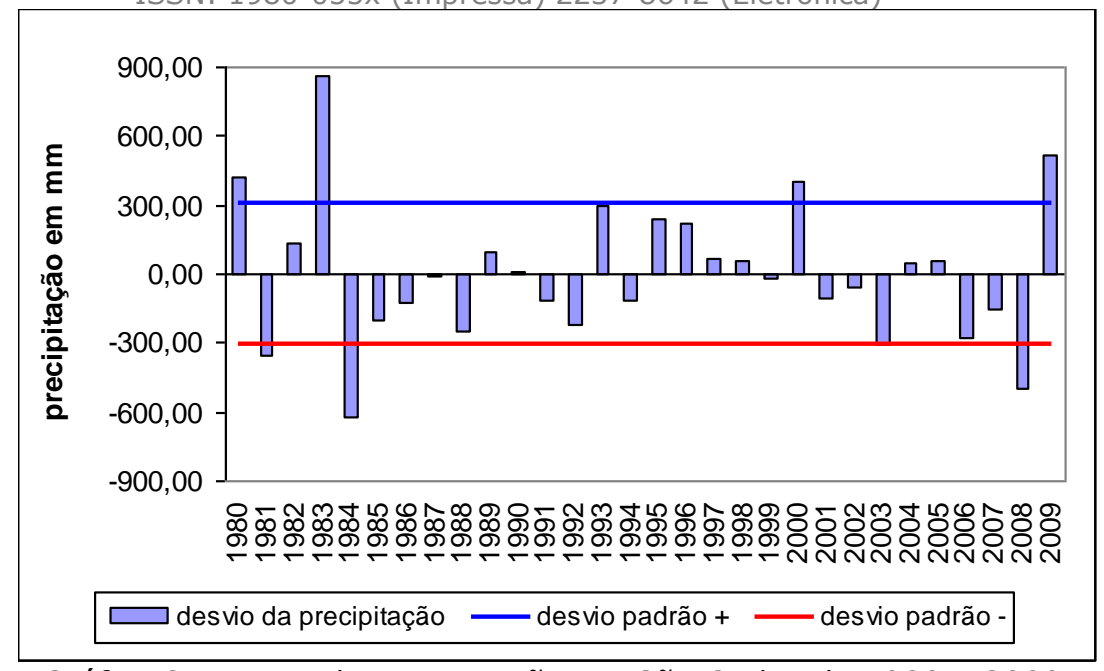

Gráfico 2: Desvio da precipitação em São Carlos de 1980 a 2009. Fonte: INMET, DAEE e EMBRAPA.

A tendência da precipitação foi analisada através da aplicação da análise da reta de tendência e apresentou variação considerada irrelevante $\left(R^{2}=0,0056\right)$ como pode ser observado no Gráfico 4. Em relação ao $\mathrm{R}^{2}$, seus valores variam entre -1 , e 1 , onde quanto mais próximo de 1 , mais significativo é o valor de correlação e tendência.

A distribuição mensal da precipitação (Gráfico 5) destaca os meses de dezembro, janeiro e fevereiro como os mais chuvosos, e junho, julho e agosto como os menos chuvosos. O Gráfico 6 demonstra também que a partir da década de 1990 os meses de janeiro e fevereiro passaram a apresentar totais mensais ainda maiores em relação a década de 1980. A afirmação fica bem evidente especialmente nos anos 1995, 1996, 1999, 2002, 2003, 2004, e 2007. Outra informação importante que pode ser extraída do Gráfico 5 é que, de modo geral, o período menos chuvoso tem se estendido de abril a outubro e o período mais chuvoso tem concentrado grandes volumes de precipitação nos meses de janeiro e fevereiro.

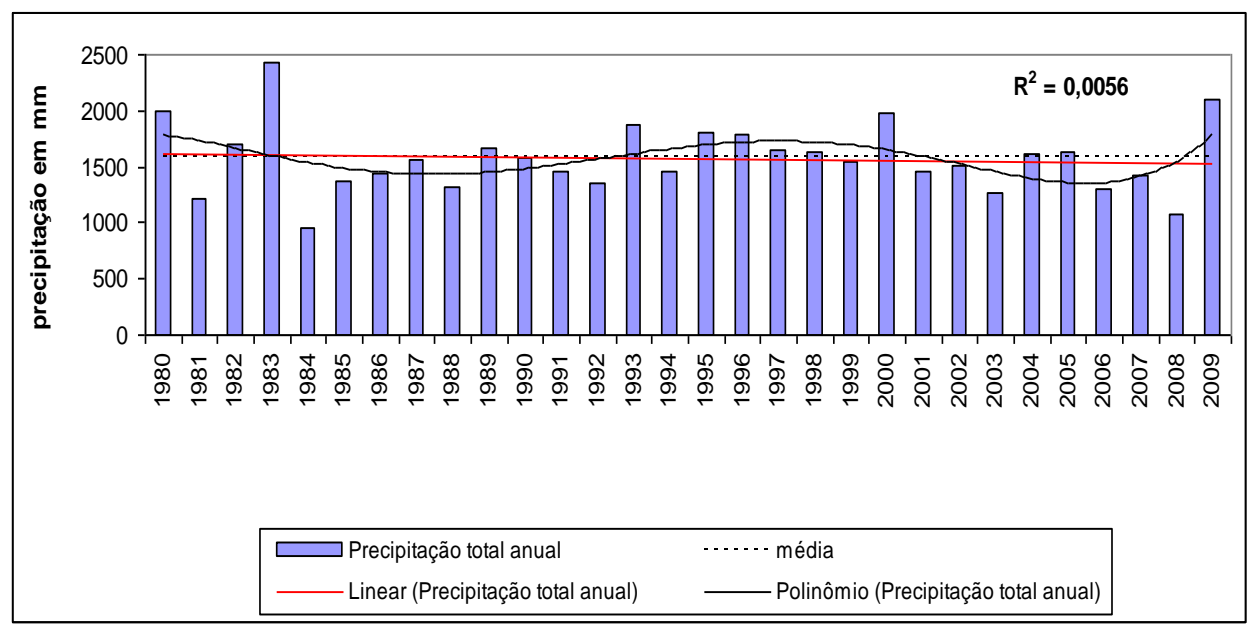

Gráfico 3: Tendência da precipitação de 1980 a 2009 em São Carlos. Fonte: INMET, DAEE e EMBRAPA. 


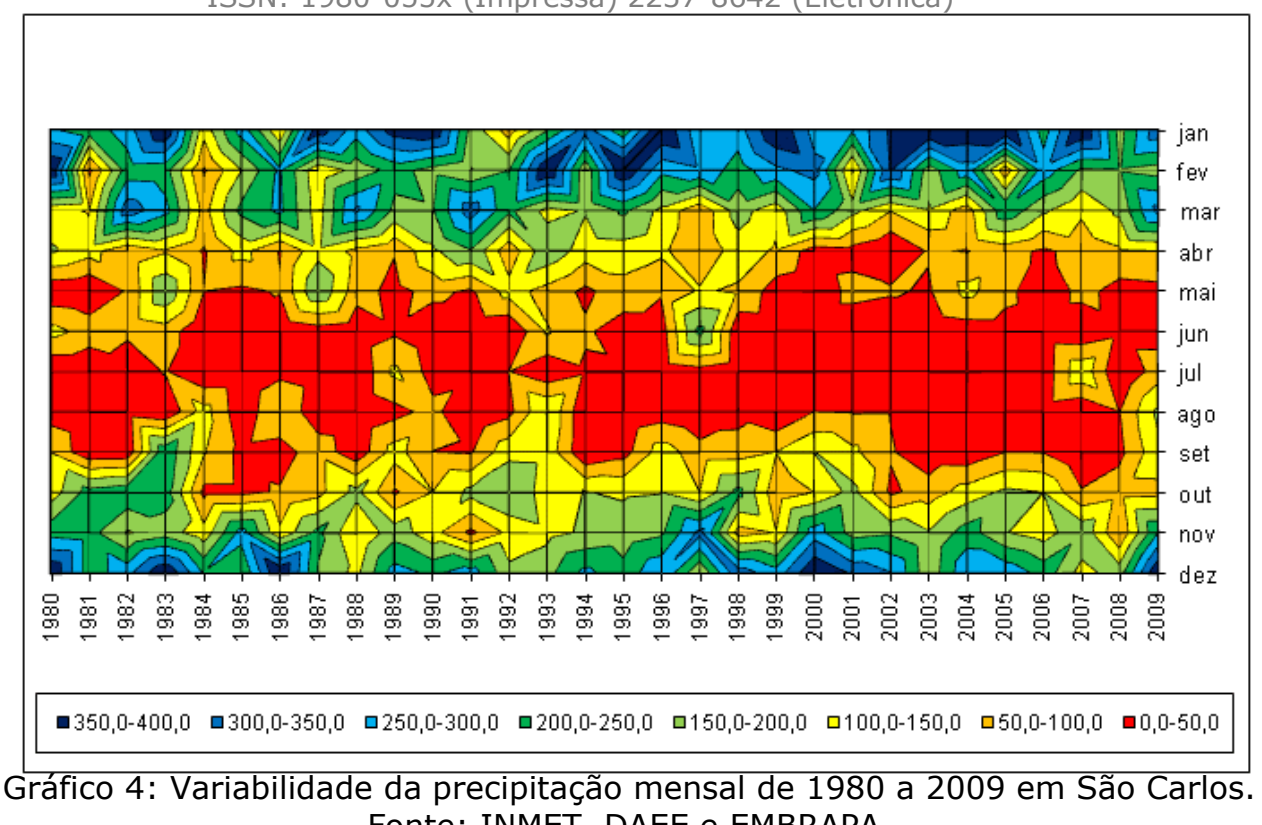

Fonte: INMET, DAEE e EMBRAPA.

A compreensão da distribuição da precipitação é fator determinante para o entendimento da ocorrência dos impactos nas áreas urbanas, sendo que a intensidade da precipitação pode desencadear grandes transtornos e prejuízos às cidades. A distribuição da precipitação máxima em 24h apresentou importantes respostas que podem ser ligadas à ocorrência de episódios de inundações e alagamentos.

Na série histórica analisada os meses que mais concentraram grandes volumes de precipitação máxima em $24 \mathrm{~h}$ foram dezembro, janeiro e fevereiro. Cabe ressaltar a ocorrência de elevada precipitação em $24 \mathrm{~h}$ também nos meses de estiagem, como pode ser observado em junho de 1980 e 1981, em agosto de 1993 e em julho de 2007. É importante ainda destacar que a partir da década de 1990 ocorreu aumento da frequência de episódios de precipitação máxima em 24h acima de 60 $\mathrm{mm}$, fato observado especialmente nos meses de janeiro e fevereiro (Gráfico 6).

A análise comparativa entre a precipitação média mensal e a precipitação máxima em 24h apresentada no Gráfico 7, esclarece ainda que episódios de precipitações potencialmente deflagradores de inundações e alagamentos podem ocorrer até mesmo nos meses com menores médias mensais de precipitação, ressaltando portanto, que a ocorrência de impactos deflagrados pela precipitação em áreas urbanas pode ocorrer em qualquer época do ano. 


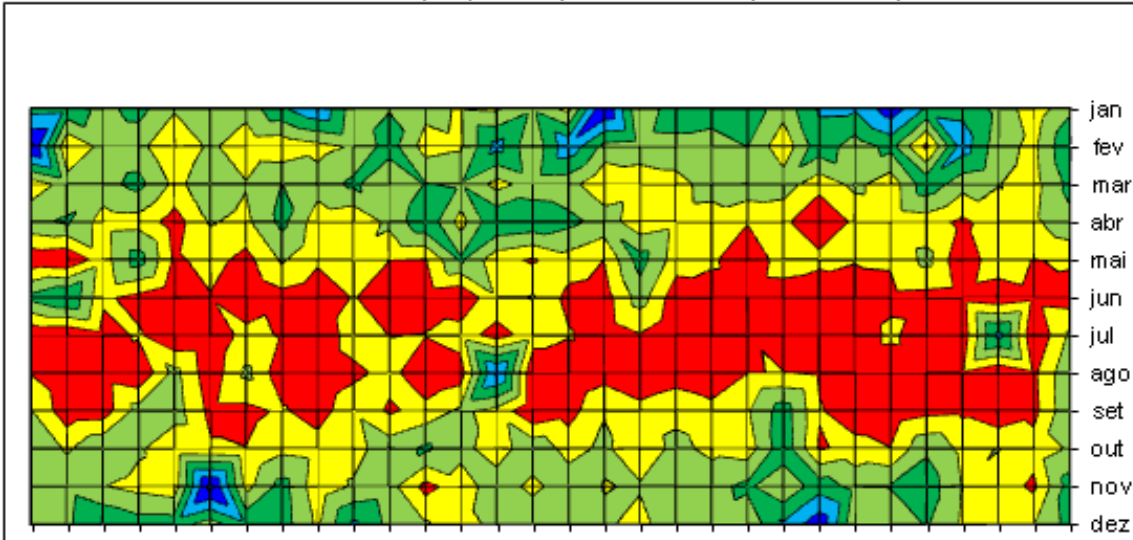

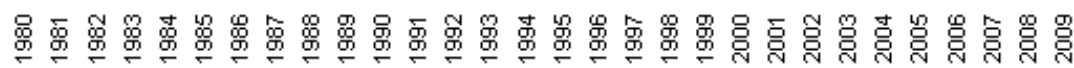

$\square 0,0-20,0 \square 20,0-40,0 \square 40,0-60,0 \square 60,0-80,0 \square 80,0-100,0 \square 100,0-120,0 \square 120,0-140,0$

Gráfico 5: Variabilidade da precipitação máxima em 24h de 1980 a 2009 em São Carlos. Fonte: INMET, DAEE e EMBRAPA

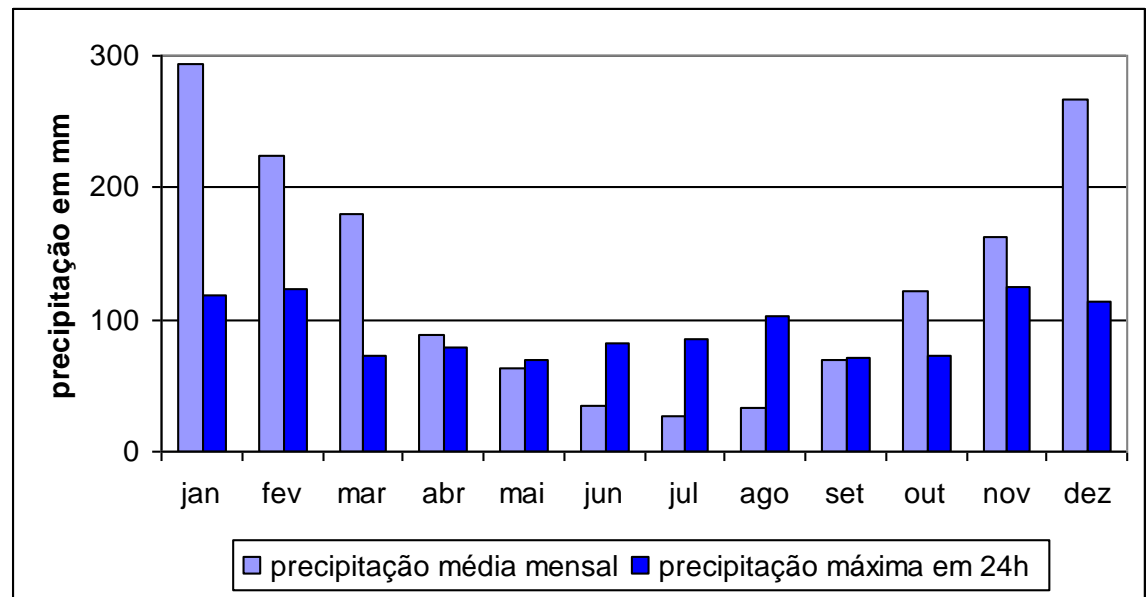

Gráfico 6: Média mensal e precipitação máxima em 24h de 1980 a 2009 em São Carlos. Fonte: INMET, DAEE e EMBRAPA.

Quanto ao número de dias com chuva durante os 30 anos analisados, podemos observar no Gráfico 8 que basicamente não ocorreu alterações significativas como demonstra a linha de tendência $\left(R^{2}=0,024\right)$. A média no período foi 101 dias com chuva e os anos que mais registraram dias com precipitação foram 1983, 2009, 1993, 1982, 1997 e 1996, respectivamente com 136, 122, 119, 113, 113 e 111 dias. 


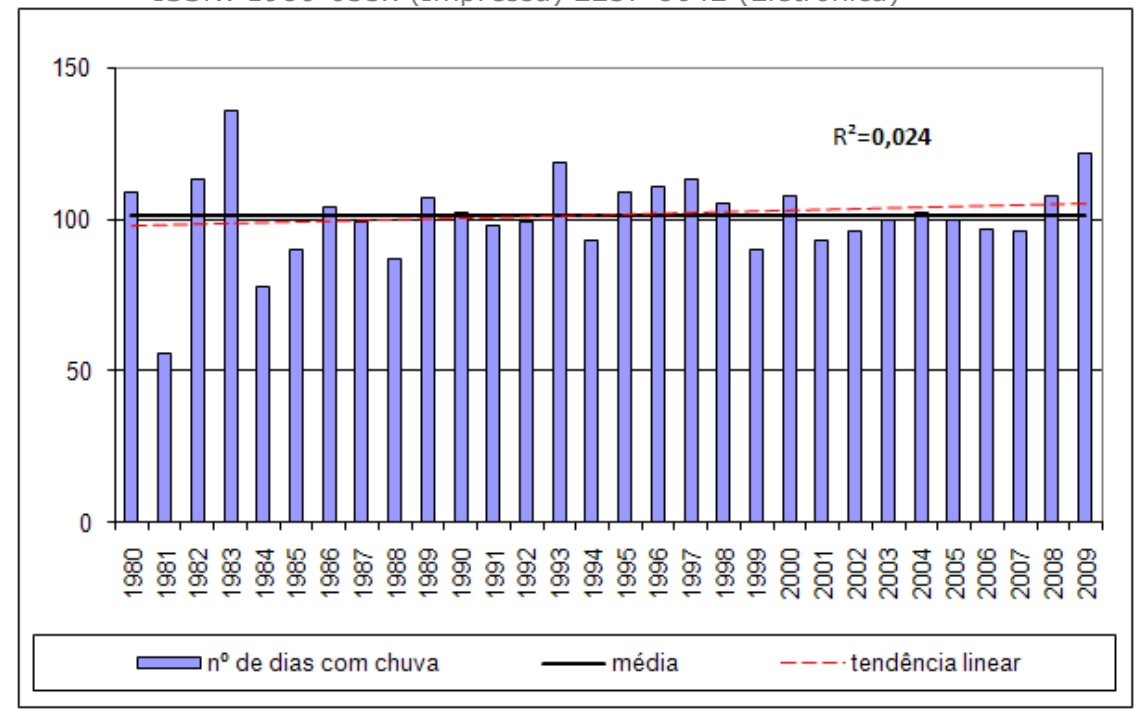

Gráfico 7: Número de dias com chuva em São Carlos no período de 1980 a 2009.

Fonte: INMET, EMBRAPA, e DAEE.

Os meses que registraram mais dias com chuva foram janeiro, dezembro e, fevereiro respectivamente com 16, 15 e 13 dias em média. (Gráfico 9). Os meses de junho, julho e agosto foram os que apresentaram as menores médias de dias com chuva: somente 3 dias.

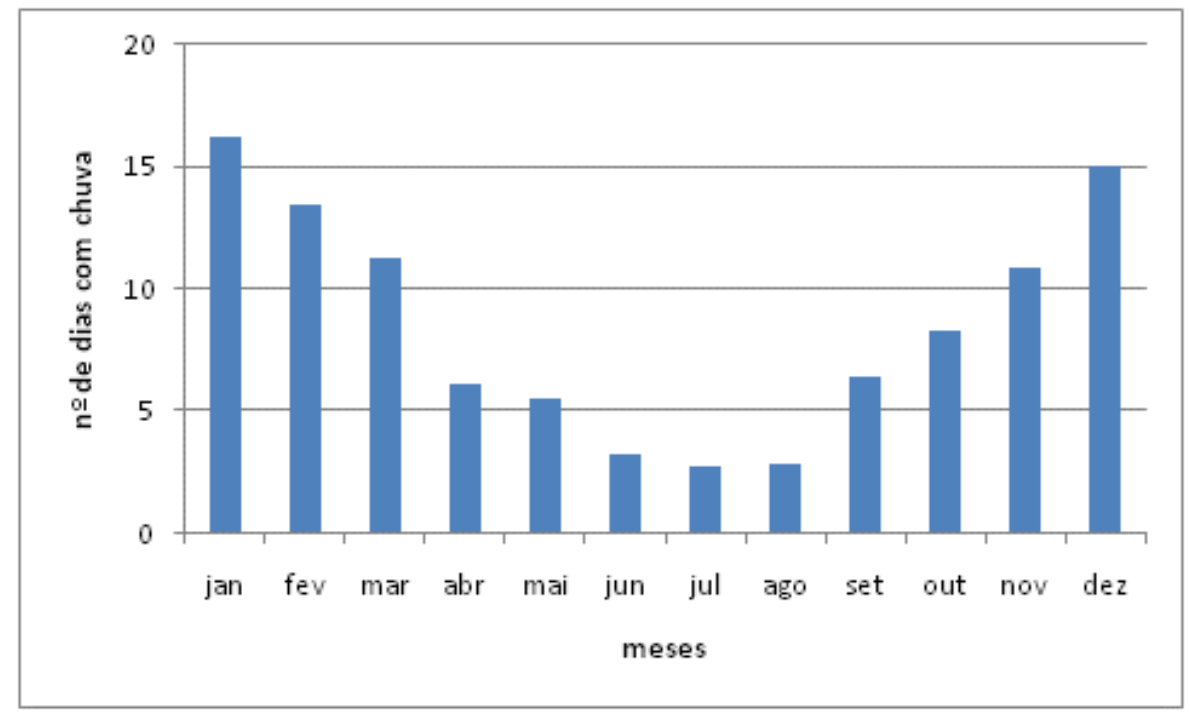

Gráfico 8: Média mensal do número de dias com chuva em São Carlos de 1980 a 2009. Fonte: INMET, EMBRAPA, e DAEE.

As análises realizadas até aqui foram de caráter quantitativo e procuraram extrair as mais variadas informações sobre as principais características da precipitação no período de 1980 a 2009. O cruzamento dessas informações levantadas sobre a distribuição da precipitação com as repercussões dos impactos pluviais registrados nos jornais locais compõe a análise qualitativa da pesquisa que tem como intuito encontrar explicações e respostas para os problemas deflagrados pela precipitação na área urbana de São Carlos.

\section{ANÁLISE QUALITATIVA DAS REPERCUSSÕES DOS IMPACTOS PLUVIAIS REGISTRADAS NOS JORNAIS}

A análise qualitativa da precipitação em São Carlos foi realizada a partir do levantamento de notícias veiculadas pela mídia impressa (jornais) de impactos 
deflagrados pela precipitação no período de 1980 a 2009. Esses dados qualitativos complementam a análise quantitativa dos dados de precipitação e ressaltam as repercussões da precipitação no espaço urbano de São Carlos.

\begin{abstract}
Os dados meteorológicos muitas vezes escamoteiam informações importantes, como a repercussão no meio social-econômico-espacial de uma sociedade. Para que possamos suprir estas lacunas, são necessárias fontes que vão além de dados quantitativos, fontes de dados qualitativos. Os dados quantitativos, como os meteorológicos, são de fundamental importância para uma explicação histórica, para que se possa observar mudanças e, porém não suficientes para a explicação das adversidades climáticas e suas repercussões geográficas. Sendo assim o jornal uma fonte extremamente importante para retratar o cotidiano e os acontecimentos de forma mais palpável e concreta, desde que este tenha credibilidade (SOUZA, 2005, p.59).
\end{abstract}

De acordo com Nunes (2007, p. 30) a mídia está cada vez mais presente no cotidiano das pessoas. Ela atinge as diversas faixas etárias e parcelas da sociedade que, no entanto, têm graus de curiosidade e envolvimento diferenciados, segundo o interesse e o conhecimento prévio de cada indivíduo em relação a um determinado tema.

Nos últimos anos as notícias relacionadas às questões climáticas têm aumentado e a explicação para tal fato está na política de conscientização ambiental desencadeada por conferências, reuniões e fóruns mundiais ligados às discussões ambientais. Segundo Ely (2008, p.146) um fato relevante para a maior publicação das notícias sobre os fenômenos climáticos foi o estabelecimento do Protocolo de Kyoto em 1997, quando foram divulgados resultados das pesquisas sobre mudanças climáticas desenvolvidas pelo Intergovernmental Panel on Climate Change (IPCC).

Nunes (2007, p. 31) ressalta que "informações sobre condições de tempo específicas, principalmente de caráter extremo, apresentam grande potencial para prevenir acidentes e perdas econômicas e/ou de vidas humanas". Ainda de acordo com Nunes (op. cit) a informação climática:

... vem recebendo maior atenção por parte da sociedade e, dessa forma, a mídia tem cedido crescente espaço para esse tipo de noticiário, ainda que o interesse por informações de tempo e clima seja maior por ocasião de fins de semana prolongados, férias, etc., ou quando ocorrem certos episódios como secas ou inundações, que afetam o ritmo das atividades econômicas e a vida das pessoas.

Deste modo, pesquisadores podem obter na mídia impressa importante fonte de dados qualitativos, especialmente sobre as repercussões de episódios climáticos deflagradores de impactos para a sociedade. Souza (2004, s/n) reitera esse fato afirmando que a fonte jornalística é grande geradora "de dados qualitativos, pois, do ponto de vista meteorológico não é possível a representação do cotidiano, ao contrário dos jornais, que se preocupam em relatar o cotidiano, com fotos e textos". O estudo aqui proposto se baseia nessas afirmações para legitimar a utilização de notícias de jornais de impactos deflagrados pela precipitação, como procedimento metodológico conveniente.

O canal dos 'impactos meteóricos', ou seja, o dos grandes aguaceiros desorganizadores eventuais da vida urbana, requer uma análise geográfica acurada dos atributos urbanos para 'responder' a tais impactos, cujo estudo exige um rumo no passado, pesquisa na memória da cidade (registros, arquivos de jornais, etc.) e a análise espacial dos episódios pluviais (MONTEIRO, 1990, p. 12). 
Segundo Sant'Anna Neto (2001), a análise de séries temporais dos elementos meteorológicos, tanto na perspectiva da identificação de anomalias, quanto dos estudos probabilísticos, muitas vezes ressente-se de um "feed back" que poderia ser fornecido através de informações que denunciem o grau de comprometimento da ação destes elementos, no que concerne à intensidade dos impactos provocados na organização do espaço e no cotidiano das populações, principalmente as que habitam as áreas urbanas.

A importância do jornal como fonte é que somente as análises climáticas, seja em escala diária ou mensal, não são suficientes para determinar a intensidade dos impactos. Entretanto, a partir da análise conjunta das notícias veiculadas nos jornais e dos dados climáticos correspondentes, pode-se identificar situações potenciais de riscos e áreas potencialmente sujeitas a impactos.

\begin{abstract}
Diferentes locais respondem de formas diversas aos mesmos fenômenos atmosféricos, de acordo com seus graus de sensitividade, adaptabilidade e vulnerabilidade da população, e as medidas voltadas à mitigação ou adaptação dos locais atingidos por fenômenos atmosféricos catastróficos dependem da integração de conhecimento científico - cujo progresso vem ocorrendo de maneira rápida, provendo previsões de tempo cada vez melhores - com as instituições governamentais e demais setores da sociedade. O Brasil, em particular, é sensível a alguns eventos de grande e mesoescala, e dado o seu baixo limiar de estabilidade físico e socioeconômico as repercussões de certas ocorrências de natureza climática até rotineiras - portanto características do regime climático dominante do lugar - podem ser bastante dramáticas. O país tem experimentado uma intensa mudança no uso da terra, o que amplifica a vulnerabilidade da sua população, especialmente a eventos extremos de precipitação, que podem ser deflagrados por condicionantes de várias ordens (NUNES, 2007, p.31).
\end{abstract}

Entretanto pesquisas que utilizam jornais como fonte de dados devem ser desenvolvidas tomando-se alguns cuidados. A mídia é tendenciosa, parcial e sensacionalista na apresentação dos fatos. Segundo Zanchetta Júnior (2004, p. 121) "nos últimos anos, as exigências de sobrevivência teriam tornado os jornais menos partidários, mais superficiais e com um requinte de sensacionalismo".

Souza (2004) destaca o caráter intencional da mídia em noticiar, por exemplo, fatos recheados de sensacionalismo ao relatar repercussões de impactos deflagrados por elementos do clima, como geadas, secas, inundações, vendavais, etc.

Zanchetta Júnior (op. cit) ressalta ainda que "para muitos a imprensa é mais poderosa que os governos, sendo capaz de interferir na vida de toda uma comunidade ou de uma sociedade, e também na individualidade dos leitores. Souza (2005, p. 60) destaca que apesar da mídia impressa "trazer uma percepção de cultura e realidade, também pode manipular os dados e inverter histórias, transformando a realidade vivida, fazendo de seus textos e imagens interesse da política do jornal".

Ainda de acordo com Zanchetta Júnior (2004):

Há dois lados nos pesquisadores sobre imprensa, aqueles que afirmam que a imprensa é incapaz de mudar o curso da história, sendo apenas "espelho da realidade", e aqueles que defendem a idéia de capacidade de manipulação da imprensa, noticiando de forma tendenciosa, encobrindo a verdade. Em geral, pode-se admitir que ambas as formas de se produzir a informação coexistem. 
Outro cuidado que deve ser destacado é quanto às imprecisões que podem ocorrer na transmissão das informações pela mídia, como exemplifica Nunes (2007, p. 30):

\begin{abstract}
A imprensa intermedia a informação entre a sua origem (que pode ser diversa, de acordo com a natureza da informação) e a sociedade, e nesse processo podem ocorrer, mesmo que não deliberadamente, distorções, simplificações, inconsistências e erros, comprometendo o seu uso adequado por quem poderia dela se beneficiar. Alguns temas são veiculados de forma descuidada e até errônea, gerando na população um sentimento de desconfiança quanto à informação, que pode ter sido em sua origem correta, mas repassada de forma inconsistente pela mídia.
\end{abstract}

Contudo é inegável o fato de que a mídia pode ser um grande meio de divulgação de fatos extremamente importantes e ter influência positiva e decisiva na vida da população. Um exemplo disso se dá através de informações meteorológicas, alertas sobre fenômenos climáticos, divulgação de pesquisas, e até mesmo como registro histórico de episódios extremos e suas repercussões.

A pesquisa realizada nos jornais encontrou 53 notícias relacionadas a episódios de inundações e alagamentos entre os anos de 1980 a 2009 em São Carlos. Durante esse período constatou-se que o número de notícias relacionadas à ocorrência de inundações e alagamentos aumentou significativamente nos jornais pesquisados (Gráfico 10).

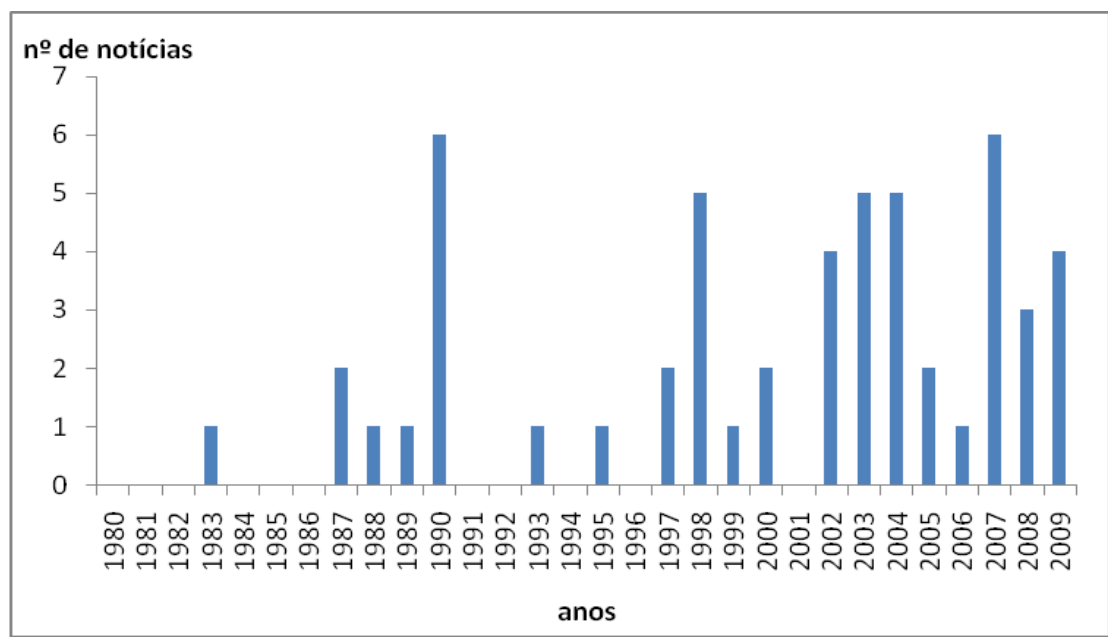

Gráfico 9: Número de notícias relacionadas às inundações e alagamentos registradas em jornais de São Carlos no período entre 1980 e 2009 Fonte: Jornal Primeira Página, Jornal A Folha e Jornal A Tribuna de São Carlos

Conforme pode ser observado no Gráfico 10, os anos de 1990 e 2007 foram os que mais registraram ocorrências de inundações e alagamentos, sendo 6 episódios em ambos. Destacaram-se também, os anos de 1998, 2003 e 2004 com registro de 5 episódios em cada. Não foram encontradas notícias sobre a ocorrência de inundações e alagamentos em 1980, 1981, 1982, 1984, 1985, 1986, 1991, 1992, 1994, 1996 e 2001.

Uma informação importante que deve ser considerada na análise do aumento das notícias de episódios de inundações e alagamentos nos jornais pesquisados, é que a partir de 1997, ano em que foi instituído o Protocolo de Kyoto, foram encontradas notícias de ocorrência de inundações e alagamentos em todos os anos, exceto em 2001 (Gráfico 10). Como já mencionado anteriormente, durante as discussões que 
precederam a elaboração do Protocolo do Kyoto, o IPCC divulgou os resultados das pesquisas sobre mudanças climáticas, e a partir de então a mídia passou a dar grande atenção às questões relacionadas ao clima e ao meio ambiente, fato que pode ter influenciado no aumento do número de notícias encontradas.

A análise do número de notícias publicadas nos jornais revelou ainda, que durante a década de 2000 , ocorreram $60 \%$ de todos os registros de alagamentos e inundações verificados nos 30 anos de estudo, o que corresponde a 32 casos. $\mathrm{Na}$ década de 1990 foram encontrados 30\% dos registros, ou seja, 16 casos. Na década de 1980 foram encontrados apenas 5 registros, cerca de $10 \%$ do total de episódios registrados de alagamentos e inundações de todo o período (Gráfico 11).

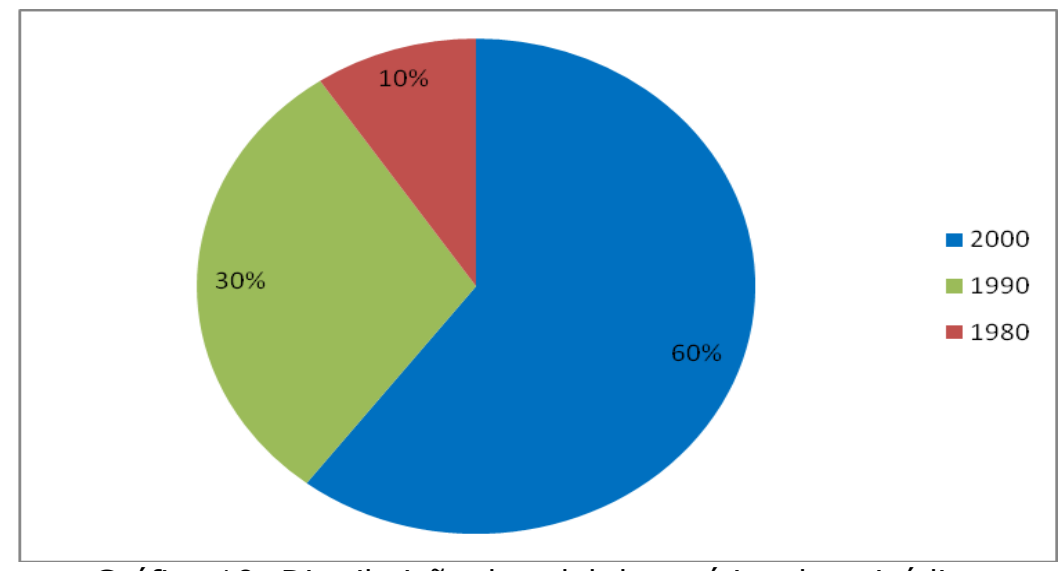

Gráfico 10: Distribuição decadal de notícias de episódios de inundações e alagamentos em São Carlos entre 1980 e 2009.

Fonte: Jornal Primeira Página, Jornal A Tribuna de São Carlos e Jornal A Folha.

$\mathrm{Na}$ análise mensal sobre o número de notícias de episódios de alagamentos e inundações, observa-se que de outubro a março (período de chuva) se concentra a maioria dos casos, ou seja, tais impactos ocorrem com maior frequência durante os dias de primavera e verão. Nos meses de janeiro, março e dezembro foram encontrados respectivamente 20, 7 e 6 episódios de inundações e alagamentos na cidade de São Carlos (Gráfico 12). Cabe destacar que nos meses de julho e agosto, os mais secos do ponto de vista dos dados meteorológicos analisados, não foram encontrados nenhuma notícia sobre a ocorrência desses impactos, como pode ser observado no Gráfico 12.

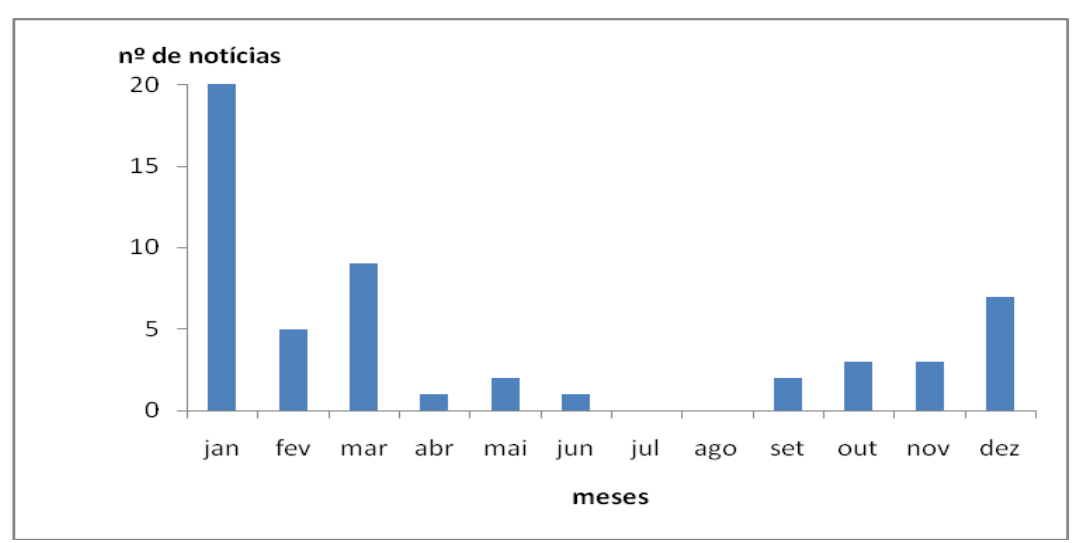

Gráfico 11: Número de notícias de episódios de alagamentos/inundações em São Carlos entre 1980 e 2009.

Fonte: Jornal Primeira Página, Jornal A Tribuna de São Carlos, Jornal A Folha. 
Para a compreensão do grande número de notícias de episódios de alagamentos e inundações encontrados nos jornais, especialmente na década de 2000, é fundamental a correlação do aumento desses episódios com o aumento da concentração da precipitação verificada nas análises pluviais, especificamente com o aumento da frequência de precipitação acima de $60 \mathrm{~mm}$ em $24 \mathrm{~h}$. Também é essencial relacionar o aumento das notícias à expansão da cidade e ao aumento da impermeabilização nas bacias hidrográficas urbanas, fato que também favorece 0 aumento dos problemas relacionados à drenagem urbana.

Em relação às condições de eficiência da drenagem urbana em São Carlos, a Figura 7, produzida pela Prefeitura Municipal e utilizada na elaboração do Plano Diretor Municipal de 2005, demonstra que a maior parte da cidade apresenta sistema de drenagem insuficiente, favorecendo a ocorrência de alagamentos e inundações urbanas.

Em estudos que analisaram os eventos pluviais causadores de episódios considerados críticos, foram ressaltados as intensidades iguais e superiores a $60 \mathrm{~mm}$ ocorridos em 24 horas, por se entender que efetivamente são os que causam mais impactos na vida da cidade, conforme constatado por Gonçalves (2003) para a cidade de Salvador, e Anunciação (2009) para a cidade de Campo Grande. Porém, como podemos observar em São Carlos, precipitações de $40 \mathrm{~mm}$ diários já possuem o potencial de deflagrar inundações e alagamentos na cidade de São Carlos. 


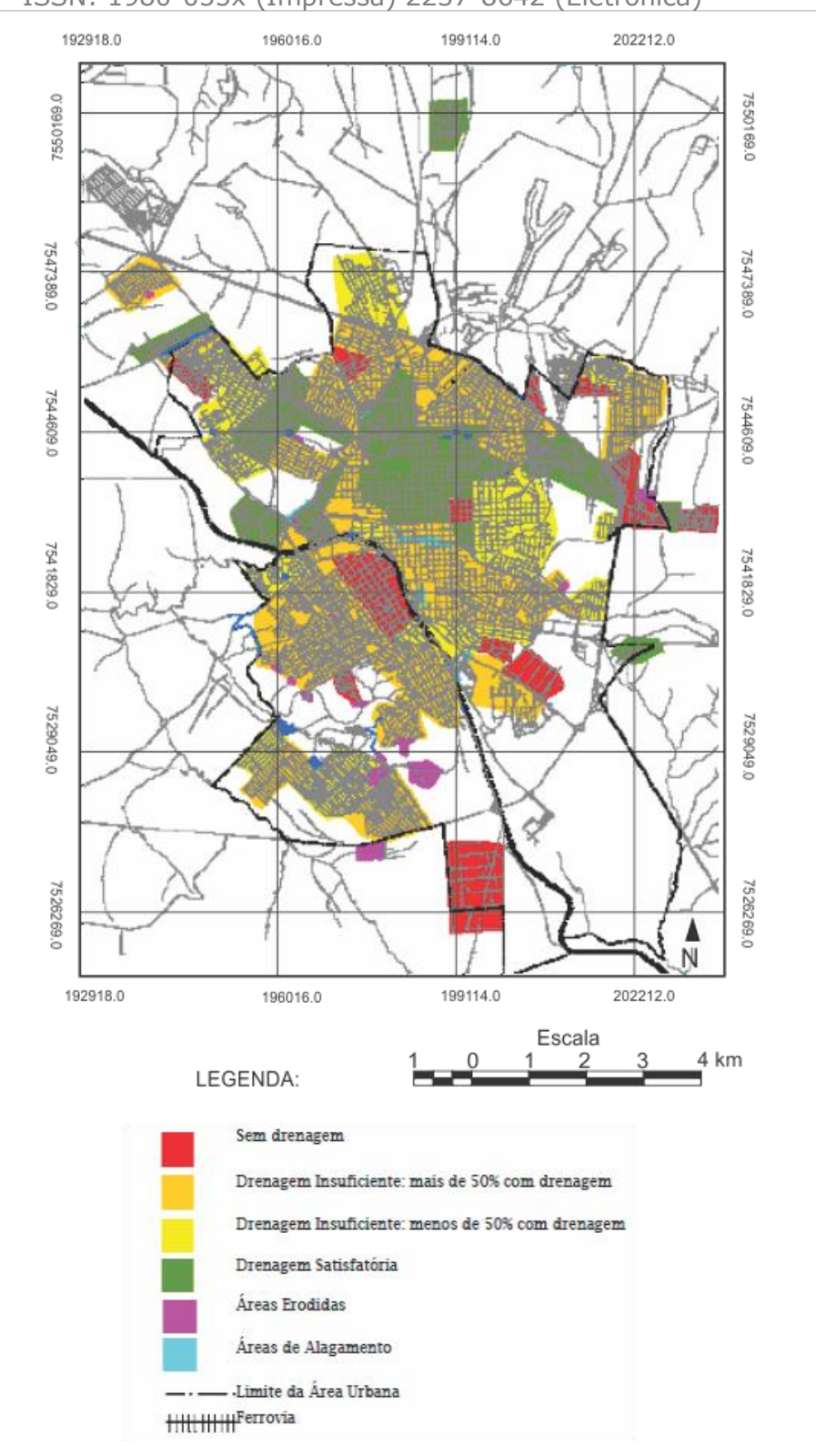

Figura 7: Condições de Infraestrutura na área urbana: drenagem, erosão e alagamentos Fonte: SMOTSP (2002) Diagnóstico - Plano Diretor de São Carlos (2005)

A Tabela 02, que apresenta a frequência de precipitação máxima em $24 \mathrm{~h}$ durante o período de 1980 a 2009, apresentou 101 registros de precipitações entre $40,1 \mathrm{~mm}$ e $50 \mathrm{~mm}, 60$ registros de precipitação entre $50,1 \mathrm{~mm}$ e $60 \mathrm{~mm}, 34$ registros de precipitação entre $60,1 \mathrm{~mm}$ e $70 \mathrm{~mm}, 16$ registros de $70,1 \mathrm{~mm}$ a $80 \mathrm{~mm}$ e superiores a $80,1 \mathrm{~mm}$ registrou 15 episódios de precipitação. Somando-se as precipitações máximas em $24 \mathrm{~h}$ acima de $40,1 \mathrm{~mm}$ de todo o período foi registrado 221 episódios. Os meses que mais apresentaram precipitações superiores a 40,1 $\mathrm{mm}$ foram janeiro (48 episódios), dezembro (45 episódios), março (30 episódios), fevereiro (35 episódios) e novembro (21 episódios). Durante todo o período, todos os meses registraram precipitações superiores a $40,1 \mathrm{~mm}$, embora os meses de junho, agosto e setembro tenham registrado respectivamente apenas 4 , 1 e 4 episódios. 
Tabela 02: Precipitação máxima em 24h do período de 1980 - 2009. Fonte: INMET 83726

\begin{tabular}{|c|c|c|c|c|c|c|c|c|c|c|c|c|c|}
\hline CLASSES & JAN & FEV & MAR & ABR & MAI & JUN & JUL & AGO & SET & OUT & NOV & DEZ & TOTAL \\
\hline $\mathbf{0 , 1 - 1}$ & 70 & 79 & 82 & 46 & 48 & 28 & 28 & 21 & 36 & 54 & 67 & 89 & 648 \\
\hline $\mathbf{1 , 1 - 5}$ & 126 & 106 & 92 & 64 & 55 & 32 & 32 & 28 & 64 & 80 & 85 & 101 & 865 \\
\hline $\mathbf{5 , 1 - 1 0}$ & 87 & 84 & 68 & 37 & 33 & 26 & 10 & 16 & 25 & 55 & 67 & 101 & 609 \\
\hline $\mathbf{1 0 , 1 - 2 0}$ & 112 & 83 & 61 & 34 & 37 & 14 & 14 & 22 & 44 & 48 & 75 & 87 & 631 \\
\hline $\mathbf{2 0 , 1 - 3 0}$ & 64 & 49 & 47 & 20 & 18 & 8 & 8 & 6 & 15 & 33 & 31 & 68 & 367 \\
\hline $\mathbf{3 0 , 1 - 4 0}$ & 43 & 26 & 22 & 8 & 6 & 2 & 3 & 1 & 11 & 17 & 30 & 31 & 200 \\
\hline $\mathbf{4 0 , 1 - 5 0}$ & 20 & 16 & 14 & 3 & 2 & 2 & 0 & 3 & 3 & 7 & 9 & 22 & 101 \\
\hline $\mathbf{5 0 , 1 - 6 0}$ & 15 & 10 & 7 & 4 & 0 & 2 & 0 & 1 & 0 & 5 & 5 & 11 & 60 \\
\hline $\mathbf{6 0 , 1 - 7 0}$ & 2 & 4 & 8 & 2 & 3 & 0 & 0 & 0 & 1 & 3 & 5 & 6 & 34 \\
\hline $\mathbf{7 0 , 1 - 8 0}$ & 6 & 1 & 1 & 2 & 0 & 0 & 1 & 0 & 1 & 0 & 2 & 2 & 16 \\
\hline $\mathbf{8 0 , 1 - 1 0 0}$ & 3 & 3 & 0 & 0 & 0 & 0 & 0 & 0 & 0 & 1 & 0 & 3 & 10 \\
\hline $\mathbf{1 0 0 , 1 - 1 5 0}$ & 2 & 1 & 0 & 0 & 0 & 0 & 0 & 0 & 0 & 0 & 0 & 1 & 4 \\
\hline$>\mathbf{1 5 0}$ & 0 & 0 & 0 & 0 & 0 & 0 & 0 & 0 & 0 & 0 & 0 & 0 & 0 \\
\hline TOTAL & 550 & 462 & 402 & 220 & 202 & 114 & 96 & 99 & 200 & 303 & 376 & 522 & 3546 \\
\hline
\end{tabular}

\section{CONSIDERAÇÕES FINAIS}

O estudo ressalta que em análises de impactos pluviais urbanos torna-se necessário considerar a organização do espaço urbano como elemento determinante. É nesse sentido que Monteiro (1991) afirma que o homem pode atuar decisivamente na intensidade dos impactos e em suas manifestações. A ocupação desordenada empreendida especialmente na fase inicial de expansão urbana, associada à ausência de sistema de drenagem eficiente em grande parte da cidade, reflete atualmente na produção de riscos associada à precipitação em São Carlos.

Os artigos dos jornais se constituíram importante fonte de registros históricos e contribuíram nas análises qualitativas. O estudo demonstrou que os alagamentos e inundações ocorreram, sobretudo, durante o período de primavera/verão, principalmente nos meses de janeiro e dezembro, e que a ocorrência desses impactos tem aumentado.

A expansão urbana de São Carlos atualmente é orientada por Plano Diretor e nesse momento torna-se fundamental considerar os impactos deflagrados pelas chuvas na área urbana e avaliar a evolução do problema na cidade, tendo em vista propostas qualificadas de ações mitigadoras do problema. Destaca-se a importância da introdução de medidas não estruturais, no campo do planejamento, como estratégia para o enfrentamento da questão. Há a necessidade de refletir sobre as novas estratégias de gerenciamento integrado, como a elaboração de Plano Diretor de Drenagem Urbana (para o gerenciamento da drenagem, dos resíduos sólidos e saneamento ambiental).

Em relação às características da precipitação, é importante destacar que houve um aumento da concentração de precipitação máxima em 24h, especialmente com o aumento da frequência de episódios acima de $60 \mathrm{~mm}$, fato observado especialmente nos meses de janeiro e dezembro. Foi observado também que durante o outono e inverno (período de estiagem) tem sido registrado quantidade cada vez menor de precipitação. Tais resultados reiteram os resultados de Setzer (1946, p.21) que constatou "a estiagem mais aguda e mais prolongada ao passo que a estação chuvosa se tornou mais curta e mais intensa no Estado de São Paulo", e tornam ainda mais 
urgentes ações para o enfrentamento dos impactos deflagrados pelas chuvas na cidade de São Carlos.

\section{REFERÊNCIAS}

AMORIM, M. C. de C. T. O Clima urbano de Presidente Prudente/SP. Tese (Doutorado em Geografia Física) FFLCH-USP, 2000.

ANUNCIAÇÃO, V. S. da. Homens fecham janelas mulheres cobrem espelhos: chuva e imprensa na cidade de Campo Grande/MS. Tese (Doutorado). FCT/UNESP, 2009.

BRANDÃO, A. M. Clima urbano e enchentes na cidade do Rio de janeiro. In: GUERRA, A. J.T.; CUNHA, S.B. (org).Impactos Ambientais Urbanos no Brasil.Bertrand Brasil 2001

CASTELLANO, M. S. Inundações em Campinas/SP entre 1958 e 2007: tendências socioespaciais e as ações do poder público. (Mestrado) Inst. Geociências. Unicamp 2010.

DEVESCOVI, R. C. B. Urbanização e acumulação: um estudo sobre a cidade de São Carlos. Arquivo de história contemporânea - UFSCar, São Carlos, 1987.

ELY, D. F.. Eventos climáticos e mídia impressa em Londrina (PR): Construindo uma abordagem a partir da análise do discurso. In: $8^{\circ}$ Simpósio Brasileiro de Climatologia Geográfica. Anais. Alto Caparaó/MG, 2008. CD-ROM.

GONÇALVES, N. M. S. Os impactos pluviais e desorganização do espaço urbano em Salvador. In: MENDONÇA, F.; MONTEIRO, C. A. de F. Clima urbano. Contexto, 2003.

GRILO, R. C. A precipitação pluvial e o escoamento superficial na cidade de Rio Claro/SP. 1992. 103 p. Dissertação (Mestrado em Geografia) - Instituto de Geociências e Ciências Exatas, Universidade Estadual Paulista, Rio Claro, 1992.

LAVEZZO FILHO, L. F., NUNES, L. H. Informações climáticas e a sociedade: o papel da mídia, com ênfase na revista Veja. In: Congresso interno e Iniciação Científica, 12, Campinas, 2004. Resumos. Campinas: UNICAMP, 2004.

MAIA, D. C. Impactos pluviais na área urbana de Ribeirão Preto - SP. Tese (doutorado) UNESP - Instituto de Geociências e Ciências Exatas. Rio Claro, 2007.

MAIA, D.C. Caracterização das enchentes na área urbana de Ribeirão Preto(SP): um enfoque através de notícias de jornal. Geografia, Rio Claro v.34, n², p. 307-327, 2009.

MENDES, H. C.; SOTO, I.; SILVA, T. G. O. da.; MENDIONDO, E. M.; Histórico de inundações na sub bacia do Gregório, São Carlos - SP: notícias de jornal de 1940 a 1996. Núcleo Integrado de Bacias Hidrográficas - EESC/USP, 2005.

MENDONÇA, F. A.; S.A.U.-Sistema Socioambiental Urbano: uma abordagem dos problemas socioambientais da cidade. In: Ed. UFPR, 2004. .(Org.) Impactos socioambientais urbanos. Curitiba:

MENDONÇA, V. M. Impactos pluviais na cidade de Presidente Prudente-SP. Monografia (Bacharelado) FCT-UNESP, Presidente Prudente, 2011.

MONTEIRO, C. A. F. Teoria de clima urbano. São Paulo, IGEO- USP, 1976.

A cidade como processo derivador ambiental e a geração de um clima urbano estratégias na abordagem geográfica. Geosul, Florianópolis, no 9, 1990. 
Clima e Excepcionalismo: conjecturas sobre o desempenho da atmosfera como fenômeno geográfico. Florianópolis: UFSC, 1991.

MOTA. S. Urbanização e meio ambiente. 3 ed. Rio de Janeiro: ABES, 2003.

NUNES, L. H. Impacto pluvial na Serra de Paranapiacaba e Baixada Santista. Dissertação de Mestrado (FFLCH, USP). São Paulo, 1990.

NUNES, L. H. O papel da mídia na difusão da informação climática: o El Niño de 1997-98. Geografia. Rio Claro: AGETEO, v.32 n. 1, jan/abr, 2007.

OLIVEIRA, R. C. de. Medidas não estruturais na prevenção e controle de enchentes em área urbanas, como subsídios para o planejamento de uso e ocupação do solo: estudo de caso: bacia do córrego do Gregório - São Carlos (SP). Dissertação (mestrado) EESC-USP, São Carlos, 1998.

PEREZ FILHO, A.; MATTOS, S. H. V. de; ORSI, L.; VICENTE, A. K.; VICENTE, L. E; Monitoramento e gerenciamento de bacias urbanas associados a inundação: diagnose da bacia do Rio Quilombo na região metropolitana de Campinas utilizando geotecnologias. Revista do Departamento de Geografia, FFLCH-USP, n. 19, p. 44 - 54, 2006.

SANT'ANNA NETO, J. L. História da climatologia no Brasil: gênese, paradigmas e a construção de uma geografia do clima. Livre-Docência - FCT/UNESP Pres. Prudente 2001.

SETZER, J. A distribuição normal das chuvas no estado de São Paulo. Revista Brasileira de Geografia - IBGE, no 1, Rio de Janeiro, 1946.

SILVEIRA, R. D. Relação entre tipos de tempo, eventos de precipitação extrema e inundações no espaço urbano de Sapé-RS. Dissertação (Mestrado) UFSM, 2007.

SOUZA, C. G. de; SANT'ANNA NETO, J. L. A imprensa como fonte de análise da adversidade climática. In: Anais. Goiânia: Associação dos Geógrafos Brasileiros, 2004.

SOUZA, C. G. de. Análise dos episódios climáticos extremos no Oeste Paulista a partir das notícias veiculadas pela imprensa local. Monografia (Bacharelado) - FCT/UNESP, Presidente Prudente, 2005.

TEODORO, P. H. M. O clima na urbanização e planejamento em Maringá/PR: uma contribuição metodológica e de aplicabilidade urbana para estudos Hidrometeóricos. Monografia (Bacharelado em Geografia) - FCT/UNESP. Presidente Prudente, 2008.

TOLENTINO, M. Estudo crítico sobre clima da região de São Carlos. EdUFScar 2007.

VICENTE, A. K. Eventos extremos de precipitação na Região Metropolitana de Campinas. Dissertação de Mestrado. Geografia. UNICAMP, 2005.

WOLLMANN C. A. M. SARTORI, da G. B. O estudo das enchentes nas diferentes linhas de pesquisa da geografia física - uma revisão teórica. Anais do XIII SBGFA. 2008.

ZANCHETTA JÚNIOR, J. Imprensa escrita e telejornal. São Paulo: Ed. UNESP, 2004. 